Bauwens, Alexandra; Degré, Aurore; Deraedt, Deborah; Döring, Ricarda; Drogue, Gilles; Huber, Nils Peter; Vanneuville, Wouter; Sinaba, Benjamin; Fournier, Maïté International assessment of future low-flow regimes and their impact on three water-related sectors in the Meuse basin - a collaborative approach

Verfügbar unter / Available at:

https://hdl.handle.net/20.500.11970/100682

Vorgeschlagene Zitierweise / Suggested citation:

Bauwens, Alexandra; Degré, Aurore; Deraedt, Deborah; Döring, Ricarda; Drogue, Gilles; Huber, Nils Peter; Vanneuville, Wouter; Sinaba, Benjamin; Fournier, Maïté (2015): International assessment of future low-flow regimes and their impact on three water-related sectors in the Meuse basin - a collaborative approach. In: Journal of River Basin Management (IAHR) 1 (13). S. 123-135. 


\title{
Autorenfassung
}

Bauwens, Degré, Deraedt, Döring, Drogue, Huber, Vanneuville, Sinaba, Fournier: International assessment of future low-flow regimes and their impact on three water-related sectors in the Meuse basin- a collaborative approach, 2014

Erstveröffentlichung in International Journal of River Basin Management 1 (2013), S. 123-135.

Für eine korrekte Zitierbarkeit ist die Seitennummerierung der Originalveröffentlichung für jede Seite kenntlich gemacht.

\section{International assessment of future low-flow regimes and their impact on three water-related sectors in the Meuse basin - a col- laborative approach}

\author{
Alexandra Bauwensa, Aurore Degréb, Deborah Deraedtc, Ricarda Döringd, Gilles Droguee, Nils Peter \\ Huberf, Wouter Vanneuvilleg, Benjamin Sinaba ${ }^{\text {h }}$ \& Maïté Fournier ${ }^{\mathrm{i}}$ \\ a Lecturer, Univ. Liège - Gembloux Agro-bio Tech., Soil-Water Systems, Passage des Déportés, 2, 5030 Gembloux, Belgium. \\ Email: alexandra.bauwens@ulg.ac.be \\ b Professor, Univ. Liège - Gembloux Agro-bio Tech., Soil-Water Systems, Passage des Déportés, 2, 5030 Gembloux, \\ Belgium. Email: aurore.degre@ulg.ac.be (author for correspondence) \\ c Lecturer, Univ. Liège - Gembloux Agro-bio Tech., Soil-Water Systems, Passage des Déportés, 2, 5030 Gembloux, Belgium. \\ Email: deborah.deraedt@ulg.amc.be \\ d Lecturer, IWW-RWTH, Mies-van-der-Rohe-Strasse 1, Aachen, Germany. Email: doering@iww.rwth-aachen.de \\ e Professor, Université de Lorraine, Laboratoire LOTERR, Île du Saulcy, CS60228, 57045 METZ cedex01. France. \\ Email: gilles.drogue@univ-lorraine.fr \\ f Doctor, Bundesanstalt für Wasserbau, Karlsruhe, Germany. Email: nils.huber@baw.de \\ g Msc, Waterbouwkundig Laboratorium (Flanders Hydraulics Research), Berchemlei, 115, 2140 Antwerpen-Borgerhout, \\ Belgium. Email: wouter.vanneuville@mow.vlaanderen.be \\ h Lecturer, IWW-RWTH, Mies-van-der-Rohe-Strasse 1, Aachen, Germany. Email: sinaba@iww.rwth-aachen.de \\ i Lecturer, EPAMA, Avenue Jean Jaurès, 26, 08000 Charleville-Mezieres, France. Email: maite.fournier@epama.fr
}

Received 23 April 2013. Accepted 30 October 2014.

There is a wide recognition of the watershed scale as the right scale for global water management, notably in the context of the water framework directive. Hence, it often refers to international management and therefore to various pre-existing regional management tools, models or even objectives. In this study, we aim at describing the collaborative assessment of climate change's effect on low-flow regime and the consequences on three water-related sectors: drinking water production, agriculture and electricity production. The paper highlights the choices that were made during the study that involved scientific teams, managers and stakeholders from the four main countries of the Meuse Basin. It shows that the methodological choices were operational and aimed at preserving existing methods and knowledge within each country. They led to hydrological scenarios comparable to the main available ensemble approaches and to methodologies well accepted within the concerned countries. The results of the project highlight and quantify the water scarcity that the three sectors will have to face by the end of the century mainly regarding the electricity production. They also show that common allocation rules are necessary to manage water demand during future lowflow periods. 


\section{Autorenfassung}

Bauwens, Degré, Deraedt, Döring, Drogue, Huber, Vanneuville, Sinaba, Fournier: International assessment of future low-flow regimes and their impact on three water-related sectors in the Meuse basin- a collaborative approach, 2014

Keywords: Climate change impacts; Meuse; low flows; agriculture; electricity sector; drinking water; international approach

\section{Introduction}

The Meuse and its catchment (Figure 1) are very important for north-west Europe. With its river of $950 \mathrm{~km}$ long, the Meuse catchment covers an area of approximately 36,000 km2 in a densely inhabited region of Europe. Almost nine millions of people live in the Meuse catchment and six millions of them depend on the Meuse for their water supply. Its transnational

Bauwens, Degré, Deraedt, Döring, Drogue, Huber, Vanneuville, Sinaba, Fournier: International assessment of future low-flow regimes and their impact on three water-related sectors in the Meuse basin - a collaborative approach International Journal of River Basin Management 1 (2013), S. 123-135.

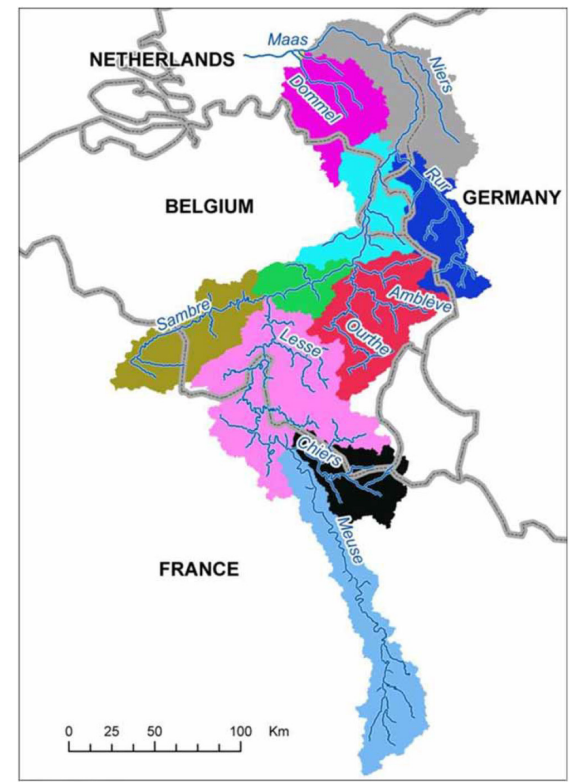

Figure 1: Catchment area of the Meuse.

catchment covers no less than five countries: France, Belgium, Great-Duchy of Luxembourg, Germany and the Netherlands. The Meuse is a rain-fed river. It is thus strongly dependent on meteorological conditions. Its discharge fluctuates considerably with seasons: it reaches $3000 \mathrm{~m}^{3} / \mathrm{s}$ in winter at the Dutch/ Walloon border and is only $10-40 \mathrm{~m}^{3} / \mathrm{s}$ in summers.

Within the framework of adaptation of the Meuse to the impacts of climate evolutions (AMICE), an Interreg IVB project, the impacts of climate change on hydrological regimes and water resources 


\section{Autorenfassung}

Bauwens, Degré, Deraedt, Döring, Drogue, Huber, Vanneuville, Sinaba, Fournier: International assessment of future low-flow regimes and their impact on three water-related sectors in the Meuse basin- a collaborative approach, 2014

management in the Meuse basin have been evaluated. Interreg IVB NWE is a financial instrument of the European Union's Cohesion Policy. It funds projects which support transnational cooperation. The aim is to find innovative ways to make the most of territorial assets and tackle shared problems of Member States, regions and other authorities. The AMICE project is done in close cooperation with the Meuse commission, stakeholders, water managers, municipalities, universities, research centres and non-governmental organizations. Past studies related to the impact of future climate on the discharges of the river Meuse concluded that floods and extreme events will become more frequent while low flows are suspected to be exacerbated in summer (Gellens and Roulin 1998, Middelkoop et al. 2001, Bauwens et al. 2011). It is now recognized that water shortages and low flows have to be considered in water resources planning. Indeed, the management of discharges into streams, the licensing of surface water and groundwater abstraction and the environmental stream management will also be affected by climate evolution (Smakhtin 2001). There is a need to provide monitoring and analysis of low flows to support integrated basin management(World Meteorological Organization 2008). In the present study, we placed emphasis on the impacts of low flows due to climate change on different sectors: agriculture, electricity and drinking water. Indeed, management problems are exacerbated during low-flow periods. Moreover, ongoing water resources development results in the gradual reduction of flow available for instream uses (Smakhtin 2001). Our aim is to propose shared methodologies in order to quantify the possible implications of low flows in these sectors. This is particularly important in order to help water management planners in their task to put in place mitigation and adaptation plans.

Recently, a series of papers have deeply discussed the impacts of climate change on hydrology in various sectors. A brief overview of the main conclusion is presented below.

\subsection{Agriculture}

Agriculture is recognized as one of the sectors that are the most impacted by climate change. It is commonly accepted that global warmingwill have effects that could be positive and/or negative, in function of the adaptive capacity of the agricultural system, the crop, the range of climate change and so on. During summer, the water deficit in the terrestrial environment will increase due to higher potential evapotranspiration (PET) (Middelkoop and Kwadijk 2001). The projected increase in temperature will favour an earlier start of the vegetation and will increase the length of the growing season, while an increase in atmospheric $\mathrm{CO}_{2}$ concentration will increase the $\mathrm{CO}_{2}$ fertilization effect which is beneficial for C3 crops (Marbaix and van Ypersele 2004). C3 and C4 plants are generally distinguished. The difference lies between enzymes which accept $\mathrm{CO}_{2}$ from air and the structure of the photosynthetic apparatus. C3 species, includingmajority of crops, are more limited in their photosynthetic process than $\mathrm{C} 4$ crops (maize). Photosynthesis of $\mathrm{C} 3$ plants increases with the increase in atmospheric $\mathrm{CO}_{2}$ while $\mathrm{C} 4$ crops are almost saturated with an increase in atm. $\mathrm{CO}_{2}$ (also called $\mathrm{CO}_{2}$ fertilization) and will thus have little effect on their photosynthetic process (Easterling et al. 2001). The water need of the plants is closely related to their photosynthetic activity. It might therefore affect the water balance. 


\section{Autorenfassung}

Bauwens, Degré, Deraedt, Döring, Drogue, Huber, Vanneuville, Sinaba, Fournier: International assessment of future low-flow regimes and their impact on three water-related sectors in the Meuse basin- a collaborative approach, 2014

\subsection{Electricity sector related to water}

Thermal power plants usually need water for their cooling system to ensure efficient operation. Therefore, thermal power plantsare often located close to a freshwater source. Freshwater can be abstracted from a lake or a river (Kugeler and Phlippen 1993). Accordingly, the energy production of thermal power plants located on the Meuse is directly affected by variations in river discharge and water temperature. There are different approaches given in the literature to assess low-flow effects on thermal power plants. Wanek et al. (2011) analysed the climate

Bauwens, Degré, Deraedt, Döring, Drogue, Huber, Vanneuville, Sinaba, Fournier: International assessment of future low-flow regimes and their impact on three water-related sectors in the Meuse basin - a collaborative approach International Journal of River Basin Management 1 (2013), S. 123-135.

\begin{tabular}{|l|l|l|l|l|l|l|l|}
\hline$P_{c}($ bar $)$ & 0.04 & 0.1 & 0.2 & 0.3 & 0.4 & 0.5 & 0.6 \\
\hline$\eta(\%)$ & 40 & 38.5 & 34 & 32.5 & 30.5 & 29.5 & 28.5 \\
\hline
\end{tabular}

Table 1: $\quad$ Efficiency factor $\eta$ in relation to condenser pressure $\mathrm{P}_{c}$, (Kugeler and Phlippen 1993)

change in Austria and the influence of changing climate on the Austrian set of hydropower plants and thermal power plants for electricity generation. In Austria, climate changehas effects similar to those in the region of the Meuse: an increase in atmospheric temperature along with a variation in yearly rainfall occurrence. This approach (Wanek et al. 2011) considers how these changes affect steam power processing in thermal power plants. The relation between cooling water temperature and efficiency factor is derived from the reciprocal dependence on pressure at the condenser. The efficiency factor $h$ depicts the proportion of the total applied heat converted into mechanical work, as defined in the energy balance of the water-steam circuit (Knies and Schierack 2006) (Table 1). Förster and Lilliestam (2010) developed a rather simple analytical model which allows the calculation of economic losses from the reduction of electrical power generation as it might be induced by climate change. The model is set up with simple and straightforward expressions for (1) the turnover of energy via the efficiency factor, giving the amount of energy which has to be cooled down and (2) the temperature transfer into the water and the temperature balance in the combined system of water body and cooling circuit. However, the model is only valid for once-through cooling systems.

Another approach adds functions to a water resources management model to analyse the effects of changing climate on power plants (Koch and Voegele 2009). The applied water resources management model Kasim (Powerplant Simulation Model) was initially developed at the Research Centre Jülich to calculate the future cooling water demand of thermal power plants. Functions for the cal- 


\section{Autorenfassung}

Bauwens, Degré, Deraedt, Döring, Drogue, Huber, Vanneuville, Sinaba, Fournier: International assessment of future low-flow regimes and their impact on three water-related sectors in the Meuse basin- a collaborative approach, 2014

culation of the capacity of power plants operating with once-through cooling and with discharge cooling were then integrated into the water management model (Koch and Voegele 2009).

Climate change can affect hydropower production mainly through changes in river flow, evaporation and dam safety. Climate change will impact precipitation and river flow positively as well as negatively; regional differences are admitted (Mideksa and Kallbekken 2010). A decrease in river discharge directly affects the attainable output capacity of the turbine of hydropower plants. This results in a decreasing electricity production (Theißing et al.2010). With increasing water temperature and decreasing discharge, freshwater abstraction will be restricted. Water temperature increase is induced by low discharge and increasing atmospheric temperatures. In some situations, power plant operators are legally obliged to constrain cooling water abstraction. These situations are defined within the EU freshwater protection directive (Directive 2006/44/EC) to secure environment for flora and fauna. National legislations exist, but differ between countries. According to the EU Directive 2006/44/EC, temperature limits may, however, be exceeded during $2 \%$ of the time.

\subsection{Drinking water}

Drinking water supply is considered as the first priority sector in all countries of the Meuse catchment. Water production in this catchment is highly dependent on water quality, but not so much on surface water quantity, as alternative sources such as groundwater can always be found. Since the AMICE project focused on water quantity, waterquality problems will not be taken into account in this study. However, one should note that water quality could face increasing problems in low-flow periods due to the increase in temperature and pollutant concentration (Bonte and Zwolsman 2010).

\section{Methodology}

The following paragraphs describe the methodologies that were elaborated on the basis of the available data, time and money within the AMICE project. All these choices were presented to a range of stakeholders and approved by them through several meetings organized at key moments during the project.

\subsection{Climate change and hydrological scenarios}

In order to build up a transnational climate scenario, an inventory of all climate experiments known and used in the countries of the Meuse catchment was performed (e.g. Blenkinsop and Fowler 2007, De Wit et al. 2007, Leander et al. 2008, Van Pelt et al. 2009). Different conclusions were drawn from this benchmarking exercise:

- There is a lack of ready-to-use tailored (i.e. bias corrected) climate simulations at the Meuse basin scale. 


\section{Autorenfassung}

Bauwens, Degré, Deraedt, Döring, Drogue, Huber, Vanneuville, Sinaba, Fournier: International assessment of future low-flow regimes and their impact on three water-related sectors in the Meuse basin- a collaborative approach, 2014

- Most of climate simulations are available only beyond 2050. Simulation including narrower time slices is important to put an emphasis on the urgency of the situation and that of adaptation.

- A large uncertainty in ensemble of climate simulations exists.

Therefore, the AMICE partners proposed to the stakeholders involved in the project to split climate model outputs into two future scenarios to study the two possible evolutions of the basin climate and hydrology: a wet one and a dry one. This pragmatic approach was adopted due to (1) a limited time and the will to use what was available and (2) the uncertainty about a drier or wetter future climate, depending on the model. However, most models indicate drier summers and wetted winters. Note that it was not in the purpose of the AMICE project to account for changes in climate variability.

The delta change approach was selected by the AMICE partners and approved by the stakeholders to produce hydrological scenarios (Figure 2). Since for a given season, monthly changes were quite similar, seasonal change factors $(\%$ for $\Delta \mathrm{P}$

Bauwens, Degré, Deraedt, Döring, Drogue, Huber, Vanneuville, Sinaba, Fournier: International assessment of future low-flow regimes and their impact on three water-related sectors in the Meuse basin - a collaborative approach International Journal of River Basin Management 1 (2013), S. 123-135.

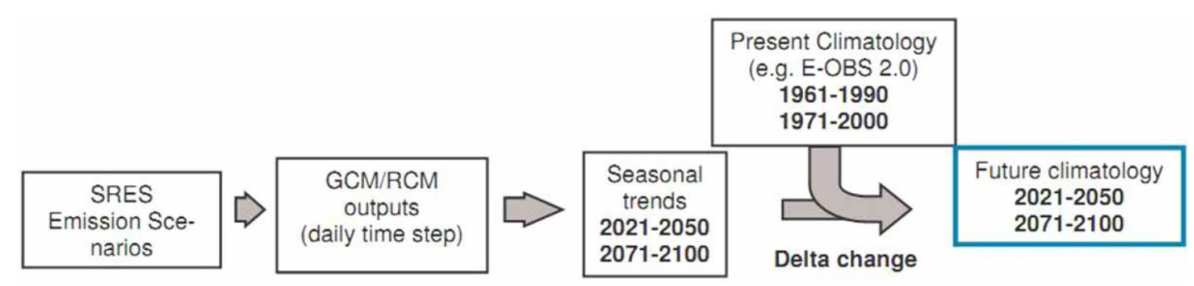

Figure 2: Flow chart of the delta change approach applied for the generation of climate scenarios.

and ${ }^{\circ} \mathrm{C}$ for $\Delta \mathrm{T}$ ) were requested to meteorological national agencies for the periods 2021-2050 and 2071-2100 based on global climate model (GCM)/regional climate model (RCM) simulations. The AMICE partners used transient numerical experiments to derive the seasonal changes for the wet and dry scenarios:

- For France, ARPEGE-Climat A1B and A2 simulations;

- For Belgium, CCI-HYDR perturbation tool;

- For Germany, WETTREG for the wet scenario and CLM for the dry scenario; and

- For the Netherlands, EU PRUDENCE project. 


\section{Autorenfassung}

Bauwens, Degré, Deraedt, Döring, Drogue, Huber, Vanneuville, Sinaba, Fournier: International assessment of future low-flow regimes and their impact on three water-related sectors in the Meuse basin- a collaborative approach, 2014

In order to produce a wet and a dry climate scenario, for each climate experiment and both time slices, we took the simulation with the extreme annual change values for the precipitation (i.e. the highest increase or the highest decrease per year). The corresponding seasonal changes in air temperature were also selected. The average seasonal changes have then been used to force a present daily climatology (i.e. E-OBS 2.0 gridded climatology) on the periods 1961-1990 or 1971-2000 (Table 2).

Once the climate scenarios were available, each country applied its own hydrological model to produce continuous discharge modelling from which high-flow and low-flow statistical analyses were performed. Coordinated hydraulic modelling was first performed from spring to mouth of the river Meuse, based on exchanges of boundary conditions between the existing models in the different regions. The modelling chains were compared and some discrepancies appeared between the models, but the limited time led us to use existing and well-accepted calibrated models.

\begin{tabular}{|l|l|l|}
\hline & Drainage area $\left(\mathrm{km}^{2}\right)$ & Weighting coefficient \\
\hline France & 10,120 & 0.31 \\
\hline Walloon & 10,888 & 0.33 \\
\hline Flanders and the Netherlands & 8662 & 0.26 \\
\hline Germany & 3338 & 0.10 \\
\hline Transnational Meuse & 33,000 & 1.0 \\
\hline
\end{tabular}

Table 2: Weighting coefficients used to create the transnational seasonal trends

\subsection{Agriculture}

Considerable field-based information exists for most major crops (Bunce 2004). Ecophysiological models are widely used to simulate the potential impacts of climate change on crop production (White et al. 2011). Assessments of potential impacts may consider economic yields but also other environmental parameters like leaf area index, in order to understand the changes in phenology. (Asseng et al. 2004). To gather information about perceived risks and foreseen impacts of climate change on agriculture, different approaches can be used, such as simulation models and experiments. free air carbon-dioxide enrichment (FACE) experiments and experiments with elevated $\mathrm{CO}_{2}$ concentration in open top-chambers permit to study the effects of a precise change on a small area of a determined crop under controlled conditions. The largest experimental systems for exposing crops to elevated $\mathrm{CO}_{2}$ concentration have a limited area, and do not include all of the vegetationatmosphere processes that affect responses of evapotranspiration to changes in stomatal conductance (Bunce 2004). These experiments are of major importance, but will not allow a large-scale screening of the impacts of climate change. Therefore, extrapolation to larger scales must be done using soil-vegetation-atmosphere models. In this study, crop growth was simulated using the environmental policy integrated climate (EPIC) model (Williams et al. 1984), with a daily time-step for the entire simulation period. The model is able to simulate a broad range of crops, including complex crop rotations over a long time period, and crop growth dependence on daily meteorological conditions. The model simulates crop response to major climate variables includingsoil water deficit and excess. The EPIC model has been extensively used for various locations and with various 


\section{Autorenfassung}

Bauwens, Degré, Deraedt, Döring, Drogue, Huber, Vanneuville, Sinaba, Fournier: International assessment of future low-flow regimes and their impact on three water-related sectors in the Meuse basin- a collaborative approach, 2014

crops. It was tested and validated in Wallonia (Sohier et al. 2009). It is assumed that a properly validated crop simulation model can be used to assess the sensitivity of the crop growth to changes in environment, such as climate change. It is based on physiological processes that describe crop responses to soil and meteorological conditions. In the EPIC model, differentsub-routines handle leaf area development, dry matter production, heat and water stresses, and tiller and growth development. Potential growth is dependent on potential solar radiation and its interception, while actual growth production is constrained by minimum and maximum temperatures, rainfall, solar radiation, soil water deficit, and nitrogen and phosphorus

Bauwens, Degré, Deraedt, Döring, Drogue, Huber, Vanneuville, Sinaba, Fournier: International assessment of future low-flow regimes and their impact on three water-related sectors in the Meuse basin - a collaborative approach International Journal of River Basin Management 1 (2013), S. 123-135.

deficiencies. The input data required to run the EPIC model include (1) daily weather information, (2) soil characterization data (European Database (ESDB v 2.0), (3) a set of parameters characterizing the crops being grown and (4) and crop management information such as emerged plant population, row spacing, seeding depth and date, harvestdate, fertilizer schedules and so on. These data are built at ULg, Gx-ABT on the basis of existing data, in collaboration with the project partners. The EPIC model considers the atmospheric $\mathrm{CO}_{2}$ concentration and its impact on photosynthesis and water used by crops. The atmospheric $\mathrm{CO}_{2}$ concentration was set to 350, 525 and $700 \mathrm{ppm}$ during, respectively, 1971-2000, 2021-2050 and 2071-2100 periods (Ewert et al. 2005; Iglesias et al. 2007) which is consistent with the climate scenarios used.

Five sub regions have been defined according to national borders: the Dutch, German, Walloon, Flemish and French Meuse basins. For each of these sub-catchments, the European soil database permits to determine the major soil encountered and to obtain a complete soil profile description. The three major cereals present in the Meuse catchmenthave been studied: corn, wheat and barley (based on the Eurostat database from 2000 to 2009). These three crops are introduced into a 3year corn - winter wheat - barley rotation. Grasslands have also been studied. Two cuts are conducted: the first on 30 May and the second on 20 August. The technical calendar and the crop characteristics have been adjusted to the Belgian situation and seemed consistent with the other countries. They are not modified for future scenarios and no irrigation is put in place. Considering no irrigation may be a too coarse assumption, but it represents the worst scenarios in terms of water availability for the plant. On the same idea, we do not consider a change in crop cultivar during the modelling, but the reader should be aware that the farmers will year after year select the more productive cultivars and so try to compensate the climate evolution. This allowed the farmer to improve their yield for the last centuries, but the quick evolution we are facing might reduce the adaptation possibility through cultivar selection. The 30-year time slices permit to have an idea of the variability of crop yields due to weather variability. 


\section{Autorenfassung}

Bauwens, Degré, Deraedt, Döring, Drogue, Huber, Vanneuville, Sinaba, Fournier: International assessment of future low-flow regimes and their impact on three water-related sectors in the Meuse basin- a collaborative approach, 2014

\subsection{Electricity production related to water}

Thermal and hydroelectric power plants are the two kinds of power plants impacted by low flows. Within the AMICE project, the impact of climate change duringlow flows is assumed to be decreasing river discharges coupled with increasing water temperature.

\subsubsection{Thermal power plants}

As mentioned before, the approach published by Koch and Voegele (2009) provides means to analyse the effects of different cooling techniques on electricity production. These formulas can therefore be used in our study to adapt the values from Förster and Lilliestam (2010) for once-through cooling to discharge cooling. As the necessary model input variables cannot be fully provided for all power plants which are under consideration, a simplification to a full application of the model to all relevant facilities has to be introduced. For this reason, exemplary calculations are performed for a selected power plant for which all necessary data are available. Values taken from Förster and Lilliestam (2010) and the adapted calculated values are not drought event-specific but annual mean values, in principle covering the years 1979-2006, which can be seen as sufficiently long to derive reliable data for a further use in AMICE. After adapting the values from Förster and Lilliestam (2010), the results can be used to determine the reduction in thermal electricity production of thermal power plants located on the Meuse for specified values of water temperature increase and discharge reduction.

\subsubsection{Hydropower plants}

Common hydroelectric power plants are installed in combination with weirs perpendicular to the flow direction of rivers. By the fact that the energy gradient between upstream and downstream water level, expressed as net drop height, is permanent, hydropower plants are suitable for base load power production (Giesecke and Mosonyi 2009). The two parameters discharge $Q$ and net drop height $\mathrm{H}_{\mathrm{n}}$ define the amount of electricity produced by the turbine of the hydropower plant. The capacity P (W) of a turbine is defined as (Strobl and Zunic 2006):

$$
P=\eta \cdot \rho \cdot Q \cdot g \cdot H_{n}
$$

with P being the capacity of the turbine $(\mathrm{W}), \eta$ the overall efficiency of the hydropower plant $(0.80-$ $0.90), \rho$ the density of water $\left(\mathrm{kg} / \mathrm{m}^{3}\right)$, g the acceleration of gravity $\left(\mathrm{m} / \mathrm{s}^{2}\right), \mathrm{Q}$ the discharge $\left(\mathrm{m}^{3} / \mathrm{s}\right)$ and $\mathrm{H}_{\mathrm{n}}$ the net drop height $(\mathrm{m})$. The attainable output $\mathrm{P}(\mathrm{kW})$ of the turbine can be assessed with the formula:

$$
\mathrm{P}=8 \cdot \mathrm{Q} \cdot \mathrm{H}_{\mathrm{n}}
$$

introduced by Strobl and Zunic (2006). The comparison of the output attainableby turbines for the reference state (today) and the selected future low-flow scenarios allows assessing the impacts of climate change on hydroelectricity production, expressed as the annual sales of each hydropower plant. 


\section{Autorenfassung}

Bauwens, Degré, Deraedt, Döring, Drogue, Huber, Vanneuville, Sinaba, Fournier: International assessment of future low-flow regimes and their impact on three water-related sectors in the Meuse basin- a collaborative approach, 2014

\subsection{Drinking water}

Water supply systems are designed to provide water in sufficient quantities and quality to satisfy the human drinking water demand. They are generally operated by a set of rules predetermined on the basis of stream flow, storage capacity and safety criteria, and are expected to meet the target water demand. The quantification of impacts due to restricted water availability during low-flow scenarios in monetary terms is hard to realize. In the case of a surface water intake stop, water suppliers have

Bauwens, Degré, Deraedt, Döring, Drogue, Huber, Vanneuville, Sinaba, Fournier: International assessment of future low-flow regimes and their impact on three water-related sectors in the Meuse basin - a collaborative approach International Journal of River Basin Management 1 (2013), S. 123-135.

to switch to alternative sources. Potential alternative water sources are groundwater pumping and water from another net operator. These measures create extra costs. An indicator of water supply performance is the probability of failure occurrence. The water supply is in a failure state when the water demand exceeds the water availability or a discharge threshold. The number and duration of water intake stops will be examined for each abstraction site in regards with mean annual discharge values and mean annual 7 day minimum flow (MAM7) with a 2-year return period at SintPieter at the Dutch border.

\section{Results and discussions}

This section presents the impacts on climate, hydrology, agriculture, electricity production and drinking water based on the proposed methodologies.

\subsection{Climate changes at the Meuse basin scale}

The transnational seasonal changes we obtained are presented in Figures 3 and 4. We compared them to the PRUDENCE RCM simulations (De Wit et al. 2007) for the end of the twenty-first century, in order to validate our procedure. Figure 4 shows that the AMICE project values are matching closely the PRUDENCE RCM simulations. The scenarios proposed by the AMICE partners are then plausible scenarios; they are not much different from the changes used in other studies on climate impacts (e.g. De Wit et al. 2007; Görgen et al. 2010). However, it does not mean that the wet or dry climate scenario will indeed happen. The water managers and decision makers were informed and should stay fully aware that our results only represent two possible future climate changes, without any absolute certainty on which climate will occur. For modelling purposes, daily PET values are needed. This second variable has been calculated from mean daily air temperature and latitude on each point of the grid through the method of Oudin et al. (2005). 


\section{Autorenfassung}

Bauwens, Degré, Deraedt, Döring, Drogue, Huber, Vanneuville, Sinaba, Fournier: International assessment of future low-flow regimes and their impact on three water-related sectors in the Meuse basin- a collaborative approach, 2014

\subsection{Hydrological changes at the Meuse basin scale}

The results of the hydrological modelling were of course variable in the different sub-watershed, but the mean perturbation factors were consistent with previous studies (De Wit et al. 2007). See, for example, a complete analysis performed in the Vesdre and Lesse basin (Bauwens et al. 2011). These results indicate that changes in the discharge regimes of the Meuse and its tributaries may already become apparentin the coming decades. Winter discharges and peak flows are expected to increase,while summer discharges decrease, reducing water availability for various sectors. The MAM7 value is expected to decrease by $10 \%$ in 2050 and by $40 \%$ at the end of the century. This is also consistent with the recent paper of Forzieri et al. (2014). These changes can have considerable socio-economic consequences. In general, climate change will increase the water demand of various sectors, particularly during summer when water availability is low, and will require an even more balanced water resources management. These results were well accepted and understood by the stakeholders and raised a new awareness, particularly regarding low flows. In Wallonia, for example, drought management plansare currently discussed. Hence, one could regret the use of different models. But it is important to notice that the local stakeholders appreciated the fact that the models developed in their region were used. It seemed to be a factor of acceptance of the results. Therefore, an ensemble modelling approach mightbe the next step for hydrological scenarios in this international watershed. It was beyond the scope of the project.

\subsection{Changes in the agriculture sector}

The evolution of yields for the three crops (wheat, barley and corn) and grasslands are presented in Figure 5. Corn crop is negatively affected by climate change. The decrease in corn yield ranges from $3 \%$ to $4 \%$ at the mid-twenty-first century (only France presents a slight increase in yields of 2\%) and
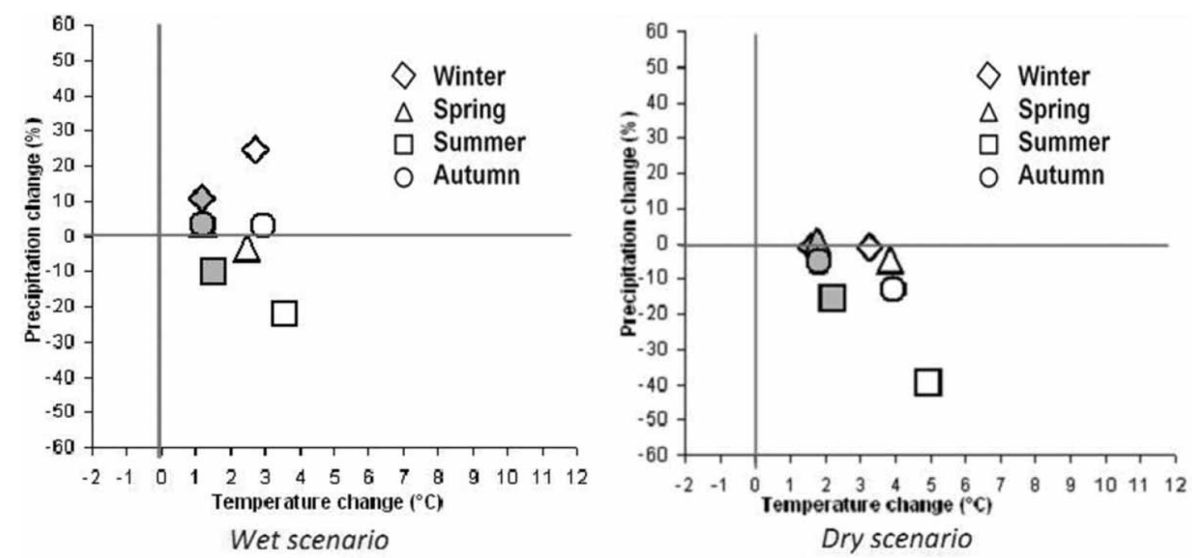

Figure 3: Seasonal trends in precipitation (\%) and air temperature $\left({ }^{\circ} \mathrm{C}\right)$ for the transnational scenario and for the two time slices (grey: 2021-2050; white: 2071-2100) - left: wet scenario; right: dry scenario. 


\section{Autorenfassung}

Bauwens, Degré, Deraedt, Döring, Drogue, Huber, Vanneuville, Sinaba, Fournier: International assessment of future low-flow regimes and their impact on three water-related sectors in the Meuse basin- a collaborative approach, 2014

Bauwens, Degré, Deraedt, Döring, Drogue, Huber, Vanneuville, Sinaba, Fournier: International assessment of future low-flow regimes and their impact on three water-related sectors in the Meuse basin - a collaborative approach International Journal of River Basin Management 1 (2013), S. 123-135.
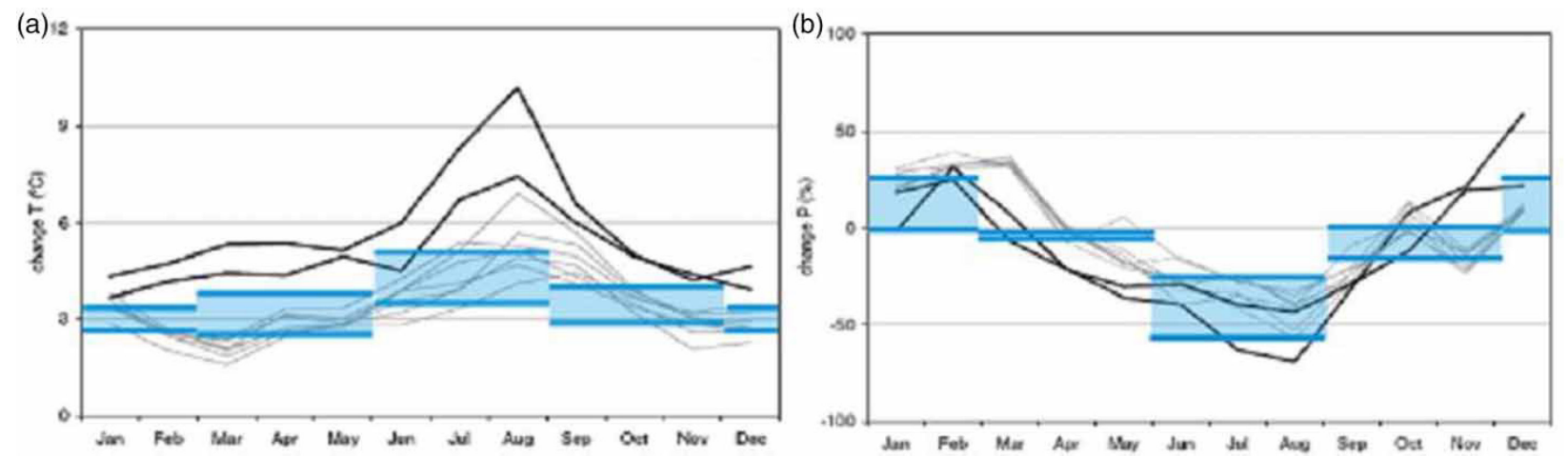

Figure 4: AMICE transnational wet and dry scenarios (blue bandwiths) vs. PRUDENCE simulations (black and grey curves) - 2071-2100 (from De Wit et al. 2007). Left: air temperature; right: precipitation.

reaches $20 \%$ at the end of the twenty-first century. The expected corn yields will be more uncertain in the future, except for Germany. Alexandrov and Hoogenboom (2000) and Cuculeanu et al. (1999) forecasted that corn yields will decrease by approximately $10 \%$ in Eastern countries at the end of the twenty-first century, mainly because of a decrease in the crop growth period. On the contrary, Olesen et al. (2007) estimated a longer crop growth period and found that corn yields will increase by $30-50 \%$ in Northern Europe. Our results show an earlier start of the growing season, mainly because of the temperature increase. But in midsummer, a water shortage causes a premature end of biomass production. It leads to a lower biomass production and lower yields. As temperature and water availability control the evolution of crop yields, we can already emphasize that it is important to use a common climate change scenario specific for the area of interest (the Meuse catchment in our case) to assess crop responses to climate evolution. A compilation of local studies will always lead to difficult comparisons because of the differences between climate scenarios.

Wheat and barley have similar behaviour and are positively affected by climate change and $\mathrm{CO}_{2}$ fertilization. The increase in wheat yields is of $8-15 \%$ at the mid-twenty-first century and reaches $16-28 \%$ at the end of the twenty-first century. But the expected yields are more uncertain too. Concerning barley, the increase in yields is of $6-20 \%$ at the mid-twenty-firstcentury and $9-21 \%$ at the end of the twenty-first century. Barley seems to be less sensitive to climate change and its yield variability is less affected than the other crops. Our results are consistent with those of Richter and Semenov (2005) who found that wheat yields will increase by 15-23\% towards 2050 in England andWales due to the better use of radiations caused by increased atmospheric $\mathrm{CO}_{2}$ concentration, 


\section{Autorenfassung}

Bauwens, Degré, Deraedt, Döring, Drogue, Huber, Vanneuville, Sinaba, Fournier: International assessment of future low-flow regimes and their impact on three water-related sectors in the Meuse basin- a collaborative approach, 2014

and the ability of wheat to maturate more quickly in a warmer climate and by that mean, avoid summer heat waves and drought stresses (Semenov 2007). According to Olesen et al. (2007), the North of Europe could face a strong increase in winter wheat yields (between $20 \%$ and $40 \%$ ), while the South of Europe could face a slight increase or a decrease in yields. Since the Meuse basin is located in the North of Europe, our results are also consistent. Ewert et al. (2005) announced a stronger yield increase, between $43 \%$ and $163 \%$, but their evaluation took into account technologies improvement (all measures related to crop management and breeding that result in yield increase). Wheat and barley benefit from temperature increase and $\mathrm{CO}_{2}$ fertilization. The water shortage in summer is quite well supported because the crops are already developed and need a dry period before harvest. Nevertheless, it is important to note that the temperature effect is limited. Rötter et al. (2011) announced a reverse effect after a $4^{\circ} \mathrm{C}$ rise. As Bakker et al. (2014) mentioned, the absolute year-to-year variability is strongly affected and needs to be taken into account when looking at the results. This study also confirms that future $\mathrm{CO}_{2}$ level may favour $\mathrm{C} 3$ plants over $\mathrm{C} 4$ due to their enhanced growth functions with higher $\mathrm{CO}_{2}$ concentration (Tubiello et al. 2007).

Grasslands are positively affected by climate change and $\mathrm{CO}_{2}$ fertilization. The grassland yield increase ranges from $10 \%$ to $19 \%$ at the mid-twenty-first century and reaches $2-21 \%$ at the end of the twenty-first century. Farmers will thus benefit particularly from an increasing mean of grassland yields, but suffer from much higher yield variability (Finger and Calanca 2011). One should note that our delta change approach could lead to the underestimation of climate change effects. With that approach only intensities of rainfall and temperature data are perturbed, frequency is not altered. However, it is now recognized that extreme events (like extreme droughts) are going to be amplified in the future.

\subsection{Changes in hydroelectricity production}

The hydropower plants and thermal power plants located along the Meuse are shown in Figure 6.

\subsubsection{Changes in thermal electricity production}

Six thermal nuclear, gas or coal power plants are located in the Meuse basin (see Figure 6). The mean annual change in thermal electricity production is calculated for the transnational dry scenario for the period 2021-2050 and 2071-2100. The results of the wet scenarios are not included here, but the results show that, whichever the scenario, the situation will not 


\section{Autorenfassung}

Bauwens, Degré, Deraedt, Döring, Drogue, Huber, Vanneuville, Sinaba, Fournier: International assessment of future low-flow regimes and their impact on three water-related sectors in the Meuse basin- a collaborative approach, 2014

Bauwens, Degré, Deraedt, Döring, Drogue, Huber, Vanneuville, Sinaba, Fournier: International assessment of future low-flow regimes and their impact on three water-related sectors in the Meuse basin - a collaborative approach International Journal of River Basin Management 1 (2013), S. 123-135.

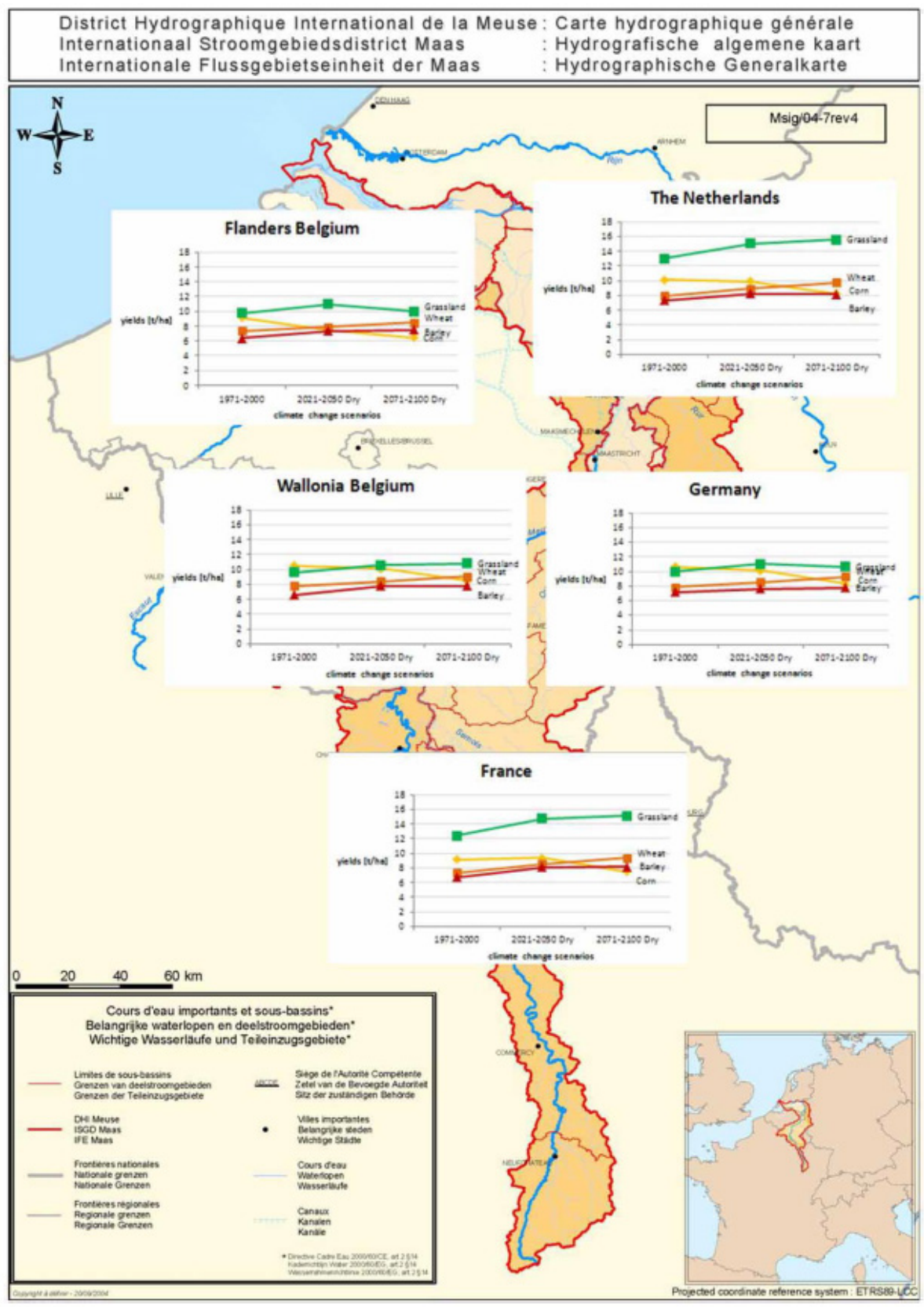

Figure 5: The evolution of yields from 1971 to 2100 under the dry scenario shows that the corn is negatively affected by climate change and wheat, barley and grasslands are positively affected. 


\section{Autorenfassung}

Bauwens, Degré, Deraedt, Döring, Drogue, Huber, Vanneuville, Sinaba, Fournier: International assessment of future low-flow regimes and their impact on three water-related sectors in the Meuse basin- a collaborative approach, 2014

improve and the operators of thermal power plants have to expect monetary damage due to climate change. Indeed, the wet scenario shows a global increase in the rainfall quantities but the seasonal distribution leads to a decrease during summer while the electricity production is affected. The determined reduction in thermal electricity production is given in Table 3. For the thermal power plants with high installed capacity, as the nuclear power plants in Chooz and Tihange, the monetary damage related to the reduction in electricity production in the future will be the most striking.

The discharge reduction for the dry 2071-2100 scenario is higher than the one for the dry 20212050 scenario. Therfore, the expected damage will be higher in the late twenty-first century than in the middle of the century

Bauwens, Degré, Deraedt, Döring, Drogue, Huber, Vanneuville, Sinaba, Fournier: International assessment of future low-flow regimes and their impact on three water-related sectors in the Meuse basin - a collaborative approach International Journal of River Basin Management 1 (2013), S. 123-135.

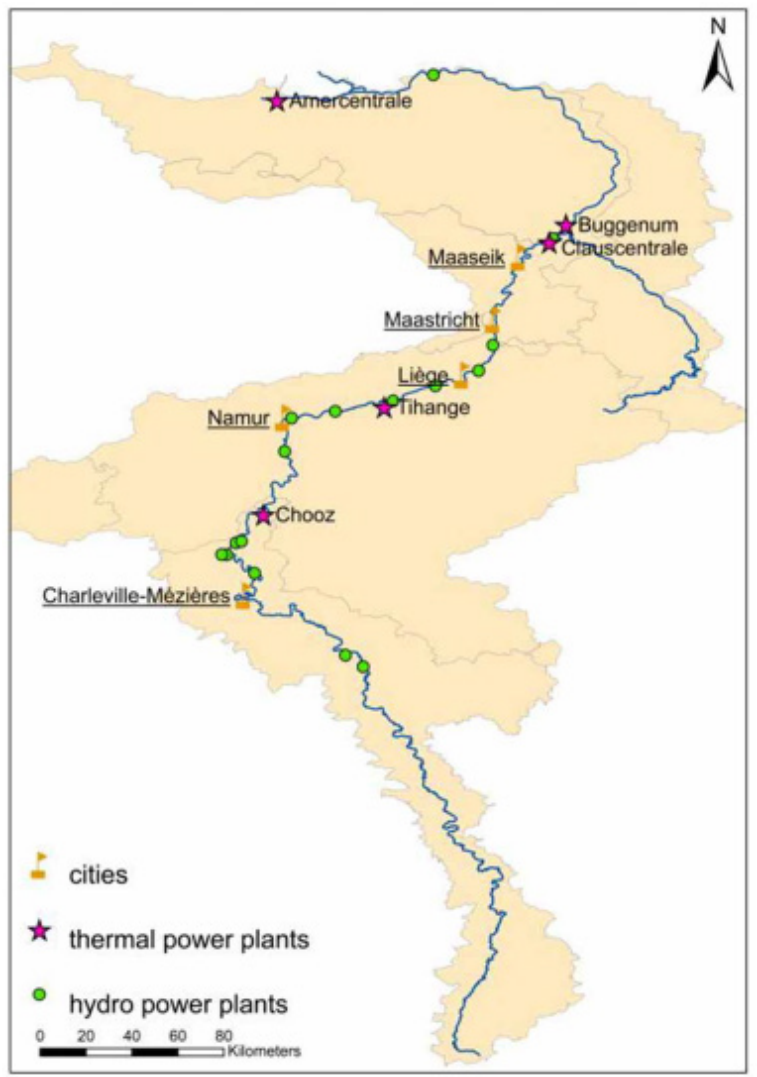

Figure 6: Location of hydropower plants and thermal power plants in the Meuse basin. 


\section{Autorenfassung}

Bauwens, Degré, Deraedt, Döring, Drogue, Huber, Vanneuville, Sinaba, Fournier: International assessment of future low-flow regimes and their impact on three water-related sectors in the Meuse basin- a collaborative approach, 2014

\subsubsection{Changes in hydroelectricity production}

The discharge values for the wet future scenarios are higher than the current mean annual discharge values. Therefore, the wet future scenarios do not modify electricity production by hydropower plants. The changes in electricity production, expressed as per cent of annual sales, for the dry scenarios are listed in Table 4 for Walloon hydropower plants. The calculations for the French hydropower plants result in no change in hydroelectricity production, because the maximum discharge which can be used by the turbines is at all times smaller than the current discharge as well as the discharges for the different future scenarios. The change in hydroelectricity production for the two Dutch hydropower plants cannot be calculated because the Meuse is dammed by weirs immediately before the hydropower plants. It is not possible to predict which amount of water will be provided for the energy production due to the lack of available data. For all Walloon hydropower plants, except Grands-Malades and Hun, hydroelectricity production decreases by more than 35\% in comparison with the actual annual hydroelectricity production for the future scenario 20212050. The hydropower plants in Grands-Malades and Hun are actually the smallest in Wallonia. Because the discharge value of the future scenario 2021-2050 is still higher than the maximum discharge value of the turbine, there is no change in hydroelectricity production for GrandsMalades and Hun in the middle of the century. For the future scenario 2071-2100, the estimated annual hydroelectricity production of most hydropower plants decreases by more than $60 \%$ in comparison with the actual annual production. The operators of Walloon hydropower plants should be aware that the decrease in river discharge induced by climate change will affect the economy of hydropower plants. However, themonetary damage of hydropower plants will be less striking than the monetary damage of thermal power plants because their installed capacity is lower.

\subsection{Changes in drinking water production}

The Meuse provides drinking water for about six million inhabitants of the Netherlands, Belgium and France. There are eight 


\section{Autorenfassung}

Bauwens, Degré, Deraedt, Döring, Drogue, Huber, Vanneuville, Sinaba, Fournier: International assessment of future low-flow regimes and their impact on three water-related sectors in the Meuse basin- a collaborative approach, 2014

\begin{tabular}{|c|c|c|c|}
\hline & & \multicolumn{2}{|c|}{ Annual reduction in electricity production (\%) } \\
\hline $\begin{array}{l}\text { Power plant (coun- } \\
\text { try) }\end{array}$ & Type & 2021-2050 & $2070-2100$ \\
\hline Chooz (Belgium) & Thermal (nuclear) & 1.90 & 8.20 \\
\hline Tihange (Belgium) & Thermal (nuclear) & 1.95 & 7.50 \\
\hline $\begin{array}{l}\text { Clauscentrale } \\
\text { (The Netherlands) }\end{array}$ & Thermal (gas) & 5.00 & 5.82 \\
\hline $\begin{array}{l}\text { Buggenum } \\
\text { (The Netherlands) }\end{array}$ & Thermal (coal) & 3.00 & 8.60 \\
\hline $\begin{array}{l}\text { Amercentrale } \\
\text { (The Netherlands) }\end{array}$ & Therme (coal) & 2.00 & 5.82 \\
\hline $\begin{array}{l}\text { Dongecentrale } \\
\text { (France) }\end{array}$ & Therme (coal) & 2.00 & 5.82 \\
\hline Lixhe & Hydroelectric & 43 & 64 \\
\hline Monsin & Hydroelectric & 57 & 73 \\
\hline Ivoz-Ramet & Hydroelectric & 39 & 62 \\
\hline Ampsin-Neuville & Hydroelectric & 35 & 60 \\
\hline Andenne & Hydroelectric & 45 & 66 \\
\hline Grands-Malades & Hydroelectric & 0 & 36 \\
\hline Hun & Hydroelectric & 0 & 11 \\
\hline
\end{tabular}

Table 3: $\quad$ Reduction in electricity production for the power plants in the Meuse basin 


\section{Autorenfassung}

Bauwens, Degré, Deraedt, Döring, Drogue, Huber, Vanneuville, Sinaba, Fournier: International assessment of future low-flow regimes and their impact on three water-related sectors in the Meuse basin- a collaborative approach, 2014

Bauwens, Degré, Deraedt, Döring, Drogue, Huber, Vanneuville, Sinaba, Fournier: International assessment of future low-flow regimes and their impact on three water-related sectors in the Meuse basin - a collaborative approach International Journal of River Basin Management 1 (2013), S. 123-135.

\begin{tabular}{|c|c|c|c|c|c|}
\hline & & & & Alternatives & \\
\hline Location & $\begin{array}{l}\text { Lincesed } \\
\text { capacity } \\
\left(\mathrm{m}^{3} / \mathrm{s}\right)\end{array}$ & $\begin{array}{l}\text { Technical } \\
\text { capacity } \\
\left(\mathrm{m}^{3} / \mathrm{s}\right)\end{array}$ & $\begin{array}{l}\text { Conditional capaci- } \\
\text { ty }\left(\mathrm{m}^{3} / \mathrm{s}\right)\end{array}$ & Source & $\begin{array}{l}\text { Drinking } \\
\text { water deliv- } \\
\text { ery }\end{array}$ \\
\hline Tailfer & - & - & - & Groundwater & No \\
\hline Broechem & 2.9 & - & $\begin{array}{l}4.0 \text { when } Q<20 \mathrm{~m}^{3 / \mathrm{s}} \\
\text { at Liège }\end{array}$ & None & Yes \\
\hline Lier/Duffel & & - & $\begin{array}{l}4.0 \text { when } Q<20 \mathrm{~m}^{3} / \mathrm{s} \\
\text { at Liège }\end{array}$ & None & Yes \\
\hline Heel & & 1,0 & - & Groundwater & - \\
\hline Brakel & & - & $\begin{array}{l}0 \text { when } Q<25 \mathrm{~m}^{3} / \mathrm{s} \\
\text { at Lith }\end{array}$ & Groundwater & Possible \\
\hline $\begin{array}{l}\text { Keizersveer } \\
\text { (Petrusplaat) }\end{array}$ & & 16 & $\begin{array}{l}0 \text { when } Q<25 \mathrm{~m}^{3} / \mathrm{s} \\
\text { at Lith }\end{array}$ & None & Yes \\
\hline
\end{tabular}

Table 4: Conditional capacities and alternative water resources

locations where river water is directly abstracted for the purpose of drinking water production. These abstraction sites are Tailfer, Heel, Scheelhoek, Keizersveer Brakel, Broechem (AlbertKanaal), Lier (Netekanaal) and bank filtration in Roosteren in the Dutch water body Grensmaas (Figure 7). The evolution of the MAM7 with a 2-year return period at Sint-Pieter at the Dutch border is simulated under the climate change scenarios for the three time slices. It is, respectively, of 38, 25 and $13 \mathrm{~m}^{3} / \mathrm{s}$ for the 1971-2000, 2021-2050 and 2071-2100 dry period.

Dry periods, which are accompanied by an increase in water temperature, could lead to water intake stops when the quality of surface water is affected. Data collection has revealed that, in the past years, several water intake stops occurred. These stops have never lasted longer than the maximum bridging period and were compensated by stored water. Moreover, they were all caused by technical defects or insufficient water quality and not by water quantity problems for the reference 


\section{Autorenfassung}

Bauwens, Degré, Deraedt, Döring, Drogue, Huber, Vanneuville, Sinaba, Fournier: International assessment of future low-flow regimes and their impact on three water-related sectors in the Meuse basin- a collaborative approach, 2014

period. Thresholds exist for some abstraction points conditioning water intake stop related to water quantity failure. This conditional capacity can limit water abstraction for Lier, Brakel and Keizersveer. However, alternatives exist for all the sites.

The assessment of the water supply system by means of annual average values would lead to a biased awareness of the system vulnerability. Even though the water balance indicates a safe and sound water supply, possible short-term periods of low flows coupled with peak demand have to be highlighted. This also holds for an assessment of the future climate impacts. When looking at the gauge in Sint-Pieter close to Maastricht and Liège, the MAM7 is estimated at $38 \mathrm{~m}^{3} / \mathrm{s}$ for the 1971 2000 period and $25 \mathrm{~m}^{3} / \mathrm{s}$ for 2021-2050. The conditional capacity for these stations is still respected. However, at the end of the twenty-first century, the MAM7 value decreases to reach $13 \mathrm{~m}^{3} / \mathrm{s}$. This discharge is smaller than the conditional capacity of $20 \mathrm{~m}^{3} / \mathrm{s}$. This will lead to water intake stop at the end of the twenty-first century due to water shortage.

\section{Lessons learnt}

During this study, different lessons have been learnt and one of the most important is to increase the awareness of the stakeholders, water managers and water users of the possible positive and/or negative impacts climate change could have on water management in various sectors. Climate change will have international impacts, it is thus necessary to have a collaborative and transnational approach to implement climate adaptation measures.

In this study, we addressed three different sectors but we did not tackle the cross sectorial management of water shortages; this should be a priority for water managers in the international watersheds. The collaborative and transnational links created during the AMICE project should be kept in the future and pushed a little forward through a more integrated modelling 


\section{Autorenfassung}

Bauwens, Degré, Deraedt, Döring, Drogue, Huber, Vanneuville, Sinaba, Fournier: International assessment of future low-flow regimes and their impact on three water-related sectors in the Meuse basin- a collaborative approach, 2014

Bauwens, Degré, Deraedt, Döring, Drogue, Huber, Vanneuville, Sinaba, Fournier: International assessment of future low-flow regimes and their impact on three water-related sectors in the Meuse basin - a collaborative approach International Journal of River Basin Management 1 (2013), S. 123-135.

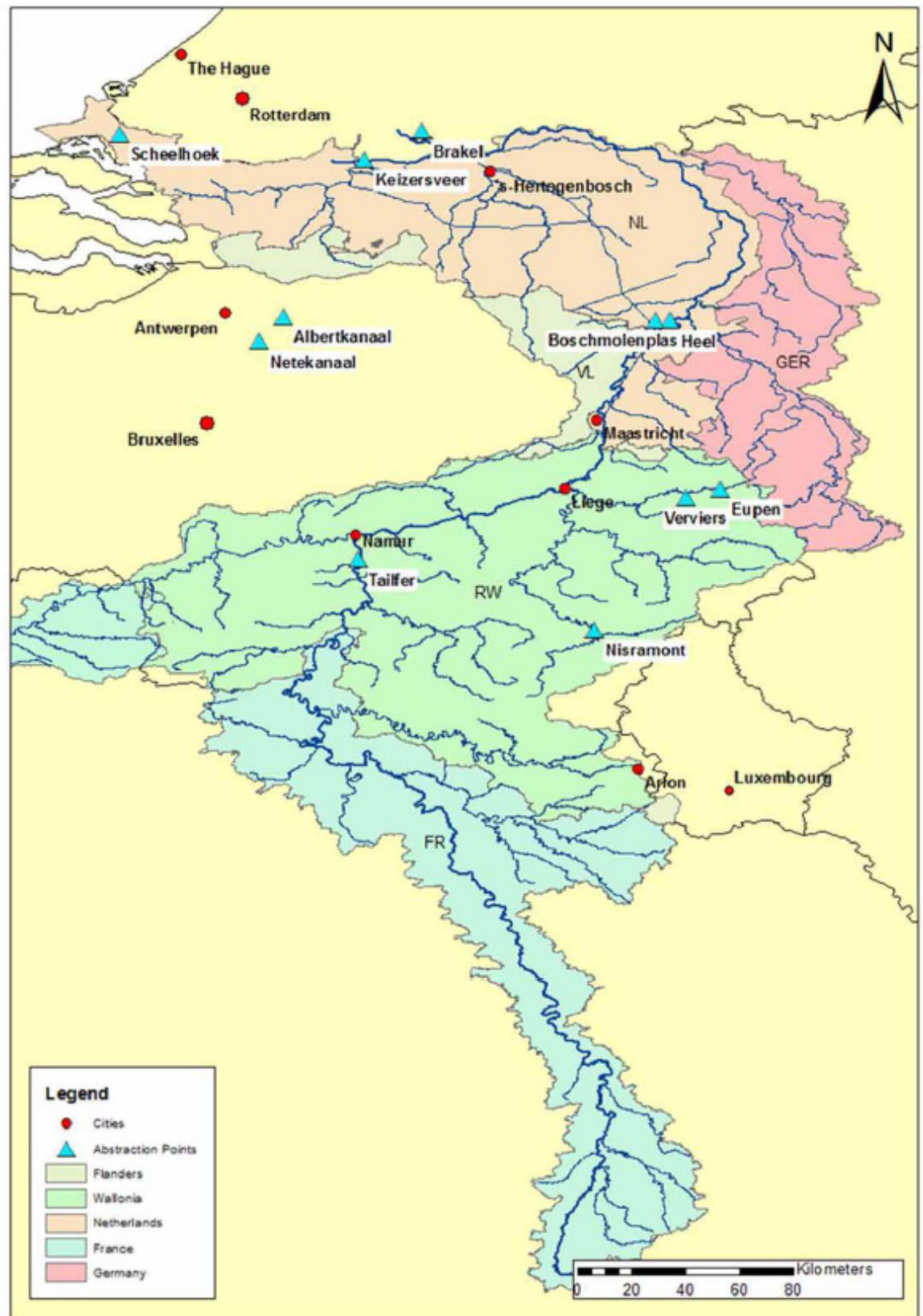

Figure 7: Location of drinking water abstraction points in the Meuse catchment. 


\section{Autorenfassung}

Bauwens, Degré, Deraedt, Döring, Drogue, Huber, Vanneuville, Sinaba, Fournier: International assessment of future low-flow regimes and their impact on three water-related sectors in the Meuse basin- a collaborative approach, 2014

approaches but keeping in mind that the acceptance of the stakeholders is a priority.

\section{Conclusions}

This study does not attempt to predict future climate, but rather to explain how a common project can raise awareness of the stakeholders about the possible future changes in agriculture production, electricity production and drinking water that might result from future climate change, with a special attention to the impacts of low flows. Low flows and drought periods are less studied in North-European countries. Nevertheless, we showed that they could have important impacts in a quite near future. We used the example of thermal power plants to show how a decrease in water discharge can affect the electricity production because of the need for cooling water. This approach is transposable to any other activity that relies on a river for its cooling system. In this application, we showed that damage for thermal power plants is much more striking than damage for hydropower plants, because thermal power plants in the Meuse catchment have much higher installed capacity.

Bauwens, Degré, Deraedt, Döring, Drogue, Huber, Vanneuville, Sinaba, Fournier: International assessment of future low-flow regimes and their impact on three water-related sectors in the Meuse basin - a collaborative approach International Journal of River Basin Management 1 (2013), S. 123-135.

Agriculture is also strongly affected by climate change but the discussion showed that it can be a positive or a negative effect, depending on the crop itself. Further attention is needed for corn in order to adapt their production or to find replacement crops in these areas. However, these results have to be taken with caution. They are dependent on the construction of climate change scenarios. The delta method used in this study changes only the magnitude of rainfall events and temperature but do not change the frequency or duration of weather events.

A data inventory of water intakes has revealed that the storage capacity for the abstracted surface Meuse water is very limited. Drinking water is the priority sector for all the countries of the Meuse catchment. Demands exist for an assessment of the water supply system vulnerability, especially under future dry scenarios. Possible future drought conditions will impose additional stress on water supply systems, which will have to face the risk of frequent water shortages and significant economic impacts. An analysis of the available data has shown that, by means of annual average values, an assessment of the Meuse water supply system vulnerability will not produce working knowledge. But the use of low-flow index permits to put in evidence water supply stress for the end of the twenty-first century. The hazard of water shortages is more related to short-term dry periods, than to a long-term trend. It implies that looking at natural variability may prove to be much more relevant than looking at gradual change. A water shortage may last several days. Identifying water shortage periods, when the water demand exceeds the water availability, enables water sup- 


\section{Autorenfassung}

Bauwens, Degré, Deraedt, Döring, Drogue, Huber, Vanneuville, Sinaba, Fournier: International assessment of future low-flow regimes and their impact on three water-related sectors in the Meuse basin- a collaborative approach, 2014

ply operators to develop adaptation strategies. Preparing agriculture, electricity production and drinking water supply for adaptation to climate change requires advanced knowledge of how climate will evolve and impact these sectors. Other sectors such as inland navigation, tourism (bathing), health (water quality) and ecology would be potentially impacted too. Competition between the different sectors may be enhanced in the future and the priority uses should be identified. The results presented in this paper permitto put in emphasis low-flow impacts and the possible consequences on three different sectors and to show that they deserve a transboundary collaboration.

\section{Acknowledgements}

I would like acknowledge the International Meuse Commission for providing the maps and authorization to publish them.

\section{Funding}

This research project was funded by the Interreg IVB NWE program through the AMICE project (Adaptation of the Meuse to the Impacts of Climate Evolutions): www.amiceproject.eu.

\section{References}

Alexandrov, V.A., and Hoogenboom, G., 2000. Vulnerability and adaptation assessments of agricultural crops under climate change in the Southeastern USA. Theoretical and Applied Climatology, 67 (1-2), 45-63.

Asseng, S., et al., 2004. Simulated wheat growth effected by rising temperature, increased water deficit and elevated atmospheric $\mathrm{CO}_{2}$. Field Crops Research, 85 (2-3), 85-102.

Bakker, A.M.R., et al., 2014. Exploring the efficiency of bias corrections of regional climate model output for the assessment of future crop yields in Europe. Regional and Environmental Change, 14 (3), 865-877.

Bauwens, A., Sohier, C., and Degré, A., 2011. Hydrological response to climate change in the Lesse and the Vesdre catchments: contribution of a physically based model (Wallonia, Belgium). Hydrology and Earth System Sciences, 15 (6), 1745-1756.

Blenkinsop, S., and Fowler, H.J., 2007. Changes in European drought characteristics projected by the PRUDENCE regional climate models. International Journal of Climatology, 27 (12), 15951610. 


\section{Autorenfassung}

Bauwens, Degré, Deraedt, Döring, Drogue, Huber, Vanneuville, Sinaba, Fournier: International assessment of future low-flow regimes and their impact on three water-related sectors in the Meuse basin- a collaborative approach, 2014

Bonte, M., and Zwolsman, J.J.G., 2010. Climate change induced salinization of artificial lakes in the Netherlands and consequences for drinking water production. Water Research, 44 (15), 4411-4424.

Bunce, J.A., 2004. Carbon dioxide effects on stomatal responses to the environment and water use by crops under field conditions. Oecologia, 140 (1), 1-10.

Cuculeanu, V., Marica, A., and Simota, C., 1999. Climate changeimpact on agricultural crops and adaptation options in Romania. Climate Research, 12 (2-3), 153-160.

De Wit, M., et al., 2007. Impact of climate change on low-flows in the River Meuse. Climatic Change, 82 (3-4), 351-372.

Easterling, W.E., et al., 2001. Comparison of agricultural impacts of climate change calculated from high and low resolution climate change scenarios: Part II. Accounting for adaptation and $\mathrm{CO}_{2}$ direct effects. Climatic Changes, 51 (2), 173-197.

Ewert, F., et al., 2005. Future scenarios of European agriculture land use. I. Estimating changes in crop productivity. Agriculture, Ecosystems and Environment, 107 (2-3), 101-116.

Finger, R., and Calanca, P., 2011. Risk managementstrategies to cope with climate change in Grassland production: An illustrative case study for the Swiss plateau. Regional Environmental Change, 11 (4), 935-949.

Förster, H., and Lilliestam, J., 2010. Modeling thermoelectric power generation in view of climate change. Regional Environmental Change, 10 (4), 327-338.

Forzieri, G., et al., 2014. Ensemble projections of future streamflow droughts in Europe. Hydrology and Earth System Sciences, 18 (1), 85-108. doi:10.5194/hess-18-85-2014

Gellens, D., and Roulin, E., 1998. Streamflow response of Belgian catchment to IPCC climate change scenarios. Journal of Hydrology, 210 (1-4), 242-258. 


\section{Autorenfassung}

Bauwens, Degré, Deraedt, Döring, Drogue, Huber, Vanneuville, Sinaba, Fournier: International assessment of future low-flow regimes and their impact on three water-related sectors in the Meuse basin- a collaborative approach, 2014

Bauwens, Degré, Deraedt, Döring, Drogue, Huber, Vanneuville, Sinaba, Fournier: International assessment of future low-flow regimes and their impact on three water-related sectors in the Meuse basin - a collaborative approach International Journal of River Basin Management 1 (2013), S. 123-135.

Giesecke, J., and Mosonyi, E., 2009. Wasserkraftanlagen, Planung, Bau und Betrieb. Heidelberg: Springer.

Görgen, K., et al., 2010. Assessment of climate change impacts on discharge in the Rhine river basin: Results of the Rhein- Blick2050 Project, CHR report, I-23, 229 p., Lelystad, ISBN 978-9070980-35-1.

Iglesias, A., et al., 2007. ReportAGRI-2006-G4-05: Adaptation to climate change in the agricultural sector. Madrid:AEAEnergy \& Environment and Universidad de Politécnica de Madrid.

Knies, W., and Schierack, K., 2006. Elektrische Anlagentechnik - Kraftwerke, Netze, Schaltanlagen, Schutzeinrichtungen. München: Carl Hanser Verlag.

Koch, H., and Voegele, S., 2009. Dynamic modelling of water demand, water availability and adaptation strategies for power plants to global change. Ecological Economics, 68 (7), 2031-2039.

Kugeler, K., and Phlippen, P.W., 1993. Energietechnik. Berlin: Springer.

Leander, R., et al., 2008. Estimated changes in flood quantiles of the river Meuse from resampling of regional climate model output. Journal of Hydrology, 351 (3-4), 331-343.

Marbaix, P., and van Ypersele, J.-P., 2004. Rapport: Impacts des changements climatiques en Belgique. Bruxelles: Greenpeace.

Middelkoop, H., and Kwadijk, J.C.J.K., 2001. Towards integrated assessment of the implications of global change for water management - The Rhine experience. Physics and Chemistry of the Earth, Part B: Hydrology, Oceans and Atmosphere, 26 (7-8), 553-560.

Middelkoop, H., et al., 2001. Impact of climate change on hydrological regimes and water resources management in the Rhine basin. Climatic Change, 49 (1-2), 105-128. 


\section{Autorenfassung}

Bauwens, Degré, Deraedt, Döring, Drogue, Huber, Vanneuville, Sinaba, Fournier: International assessment of future low-flow regimes and their impact on three water-related sectors in the Meuse basin- a collaborative approach, 2014

Mideksa, T.K., and Kallbekken, S., 2010. The impact of climate change on the electricity market: a review. Energy Policy, 38 (7), 3579-3585.

Olesen, J.E., et al., 2007. Uncertainties in projected impacts of climate change on European agriculture and terrestrial ecosystems based on scenarios from regional climate models. Climatic Change, 81 (1 supplement), 123-143.

Oudin, L., Michel, C., and Anctil, F., 2005. Which potential evapotranspiration input for a rainfallrunoff model? Part 1 - Can rainfall-runoff models effectively handle detailed potential evapotranspiration inputs? Journal of Hydrology, 303 (1-4), 275- 289.

Richter, G.M., and Semenov, M.A., 2005. Modelling impacts of climate change on wheat yields in England and Wales: assessing drought risks. Agricultural Systems, 84 (1), 77-97.

Rötter, R.P., et al., 2011. What would happen to barley production in Finland if global warming exceeded 8C? A model based assessment. European Journal of Agronomy, 35 (4), 205-214.

Semenov, M.A., 2007. Development of high-resolution UKCIP02-based climate change scenarios in the UK. Agricultural and Forest Meteorology, 144 (1-2), 127-138.

Smakhtin, V.U., 2001. Low flow hydrology: A review. Journal of Hydrology, 240 (3-4), 147-186.

Sohier, C., Degré, A., and Dautrebande, S., 2009. From root zone modelling to regional forecasting of nitrate concentration in recharge flows - The case of the Walloon Region (Belgium). Journal of hydrology, 369 (4), 350-359.

Strobl, T., and Zunic, F., 2006. Wasserbau, Aktuelle Grundlagen - Neue Entwicklungen. Berlin: Springer.

Theißing, M., et al., 2010. Kraftwerke im Klimawandel - Auswirkungen anf die Erzeugung von Elektrizität. Kapfenberg: FH JOANNEUM Gesellschaft mbH.

Tubiello, F.N., Soussana, J.-F., and Howden, S.M., 2007. Crop and pasture response to climate change. Proceedings of the National Academy of Sciences of the United States of America, 104 (50), 19686-19690.

Van Pelt, S.C., et al., 2009. Discharge simulations performed with a hydrological model using bias corrected regional climate model input. Hydrology and Earth System Sciences, 13 (12), 2387-2397. 


\section{Autorenfassung}

Bauwens, Degré, Deraedt, Döring, Drogue, Huber, Vanneuville, Sinaba, Fournier: International assessment of future low-flow regimes and their impact on three water-related sectors in the Meuse basin- a collaborative approach, 2014

Wanek, M., Theibing, M., and Zisler, M., 2011. Kraftwerke in Klimawandel - Auswirkungen auf die Erzeugung von Elektrizität, 7. Wien: Internationale Energiewirtschaftstatung an der TU Wien.

White, J.W., et al., 2011. Methodologies for simulating impacts of climate change on crop production. Field Crops Research, 124 (3), 357-368.

Williams, J.R., Jones, C.A., and Dyke, P.T., 1984. A modelling approach to determining the relationship between erosion and soil productivity. Transactions of the ASABE, 27 (1), 129-144.

World Meteorological Organization, 2008. Manual on low-flow: estimation and prediction, Operational Hydrology Report, 50, 136. 